Original Research Paper

\title{
Meningkatkan Keterampilan Menulis Teks Narasi dengan Menggunakan Silent Video pada Siswa SMA Negeri 1 Mataram
}

\author{
Sri Ngayomi Widiprihati ${ }^{1}$ \\ 1Sekolah Menengah Atas Negeri 1 Mataram, Kota Mataram, Nusa Tenggara Barat, Indonesia
}

\section{DOI: https://doi.org/10.29303/jcar.v3i2.898}

${ }^{*}$ Corresponding Author:

Sri Ngayomi Widiprihati Sekolah Menengah Atas Negeri 1 Mataram, Kota Mataram, Nusa Tenggara Barat.

Email:

ngayomi66@gmail.com

\begin{abstract}
Penelitian ini bertujuan menguraikan upaya meningkatkan keterampilan menulis teks narasi pada siswakelas XI Lintas Minat Bahasa Inggris SMAN 1 Mataram tahun pelajaran 2020/2021. Penelitian ini merupakan penelitian tindakan kelas yang menerapkan pola siklus dengan tahapan perencanaan, tindakan, observasi, dan refleksi. Pengumpulan data dilakukan dengan metode observasi dan dokumentasi. Analisis data dilakukan dengan melihat peningkatan aktivitas guru dan siswa, serta hasil belajar siswa persiklus. dan Pembahasan dilakukan secara deskriptif. Berdasarkan hasil analisis disimpulkan bahwa penggunaan silent video dengan pendekatan cooperative learning terbukti secara signifikan dapat meningkatkan keterampilan peserta didik dalam menulis teks naratif. Hal ini ditunjukkan dengan peningkatan perolehan nilai rata-rata peserta yaitu 69,9 pada siklus I menjadi 77,3 pada siklus II dan ketuntasan klasikal meningkat dari dari $78 \%$ pada siklus I menjadi $94 \%$ pada siklus II. Kekatifan siswa juga meningkat dari $72 \%$ pada siklus I menjadi $86 \%$ pada siklus II.
\end{abstract}

Keywords: menulis; narasi; silent video

\section{Pendahuluan}

Dalam berbahasa Inggris, ada empat keterampilan yang wajib dikuasai, yaitu: menulis (writing), membaca (reading), mendengarkan (listening) dan berbicara (speaking). Dari keempat keterampilan ini, menulis merupakan keterampilan yang paling sulit karena mengandung unsur-unsur yang sangat kompleks dan membutuhkan banyak keahlian dan kreatifitas apalagi dalam berbahasa Inggris (Widiyarto, 2017). Begitu kompleksnya keterampilan ini, sehingga kesulitan dalam menulis banyak dialami oleh siswa dari kelas rendah sampai kelas tinggi (Amilia, 2018).

Alviano et al., (2021) telah melakukan analisis kemampuan siswa dalam menulis teks narasi. Dalam penelitiannya menunjukkan bahwa kemampuan peserta didik dalam menulis teks narasi dalam berbagai aspek masih sangat kurang. Dari keseluruhan indikator bahkan mencapai $45 \%$ tidak mencapai KKM. Kurangnya kemampuan peserta didik ini terjadi karena faktor metode pembelajaran yang kurang sesuai. Misalnya masih banyak guru yang menggunakan metode konvensional seperti ceramah, sehingga peserta didik merasa bosan dan kurang antusias menerima materi. Oleh karena itu, peningkatan inovasi dalam metode pembelajaran sesuai dengan perkembangan siswa sangat penting untuk dilakukan, terutama dalam kondisi pandemi saat ini. Banyak peserta didik mengalami kesulitan dalam belajar, khususnya dalam menulis teks narasi. Kesulitan tersebut timbul karena kurangnya minat peserta didik dan tidak ada inovasi dalam proses pembelajaran (Gultom, 2012). Salah satu inovasi yang dilakukan oleh guru untuk peningkatan motivasi dan kemampuan siswa dalam menulis adalah 
dengan menggunakan video dalam kegiatan belajar mengajar.

"Writing is a way to share personal meanings" (Hayland, 2014). Artinya, dengan menulis, seseorang mampu mengemukakan ide atau tujuan dari buah pikiran dalam bentuk yang lebih jelas sehingga dapat dimengerti dengan baik oleh orang lain. Orang lain dapat membangun pandangan mereka terhadap sesuatu melalui keterampilan menulis.

Menulis adalah keterampilan produktif yang mensyaratkan peserta didik untuk mengekspresi ide mereka dalam bentuk tulisan yang memerlukan tidak hanya memahami isi cerita akan tetapi juga penguasaan elemen keterampilan lain seperti menggunakan atau pemilihan kosakata yang tepat, ejaan yang benar, dan struktur kalimat yang tepat tetapi juga kreatifitas dalam menuangankan ide. Hal ini salah satunya nampak pada lambatnya peserta didik dalam memenuhi tugas menulis serta rendahnya nilai ulangan harian. Oleh karena itu, peserta didik perlu belajar bagaimana menulis paragraf yang baik dengan memahami struktur teks, menggunakan metode yang tepat dan terus berlatih menulis.

Salah satu metode yang digunakan oleh guru dalam rangka meningkatkan ketertarikan dan kemampuan siswa dalam menulis teks adalah melalui media teknologi berupa silent video. Banyak penelitian telah dilakukan sebelumnya menunjukkan bahwa terjadi peningkatan motivasi siswa dalam belajar menggunakan video. Salah satunya dalam penelitian yang telah dilakukan Agustian (2012) dalam disertasinya mengemukakan bahwa terjadi peningkatan motivasi belajar siswa hingga 20\% dalam menulis teks narasi. Penelitian lain yang dilakukan oleh Sarica dan Usluel (2016) menunjukkan peningkatan yang signifikan dalam hal kapasitas memori visual dan keterampilan menulis peserta didik menggunakan kelompok eksperimen dan kontrol. Namun, tidak ada perbedaan yang signifikan secara statistik yang diamati antara kelompok. Berdasarkan kompetensi dasar, peserta didik diharapkan dapat membedakan fungsi sosial, struktur teks, dan fitur bahasa teks naratif terkait dengan cerita rakyat berdasarkan konteks.

Selain itu, penggunaan multimedia berupa video untuk kreasi digital dapat memberikan efek positif pada peserta didik untuk membuat dan melengkapi produk tertulis. Satu studi seperti itu menunjukkan bahwa penulis yang berjuang mungkin termotivasi oleh teknologi digital karena mereka lebih melek huruf dalam literasi baru dan menggunakan ini untuk perancah keaksaraan tradisional. Penggunaan lingkungan belajar digital di ruang kelas menunjukkan peningkatan dalam "menulis peserta didik sukarela, dan meningkatkan skor prestasi standar pada tugas menulis" (Warren et al., 2008).

Dengan kata lain, menggunakan video dalam proses pembelajaran dapat sangat bermanfaat bagi peserta didik karena membahas gaya belajar yang berbeda dari pembelajar visual dan pendengaran. Selain itu, video mewakili irisan kehidupan yang realistis. Ini memvisualisasikan hal-hal abstrak menjadi hal-hal konkret. Oleh karena itu, video merupakan salah satu media yang dapat dimanfaatkan untuk meningkatkan kemampuan siswa dalam menulis, termasuk dengan silent video.

\section{Metode}

Subjek penelitian ini adalah 32 orang siswa di kelas XI Lintas Minat Bahasa Inggris SMAN 1 Mataram tahun ajaran 2020/2021 dengan kegiatan pembelajaran pada KD 3.5 Kurikulum 2013. Penelitian dilaksanakan bulan Oktober sampai dengn Desember 2020. Penelitian dilaksanakan dalam masa pandemi covid-19, sehingga dalam pelaksanaannya memperhatikan penerapan protokol kesehatan sesuai dengan ketentuan dan Surat Edaran Gubernur NTB maupun Surat Edaran Kepala Dinas Pendidikan dan Kebudayaan Provinsi NTB. 
Penelitian ini adalah penelitian tindakan kelas menggunakan desain dengan dua siklus. Setiap siklus dilaksanakan selama 2 kali pertemuan. Masing masing pertemuan memakan waktu selama 90 menit. Setiap tahapan siklus terdiri dari perencanaan, pelaksanaan, observasi dan refleksi. Hal ini seperti yang dinyatakan oleh Kemmis \& Mc. Taggert, 1988)

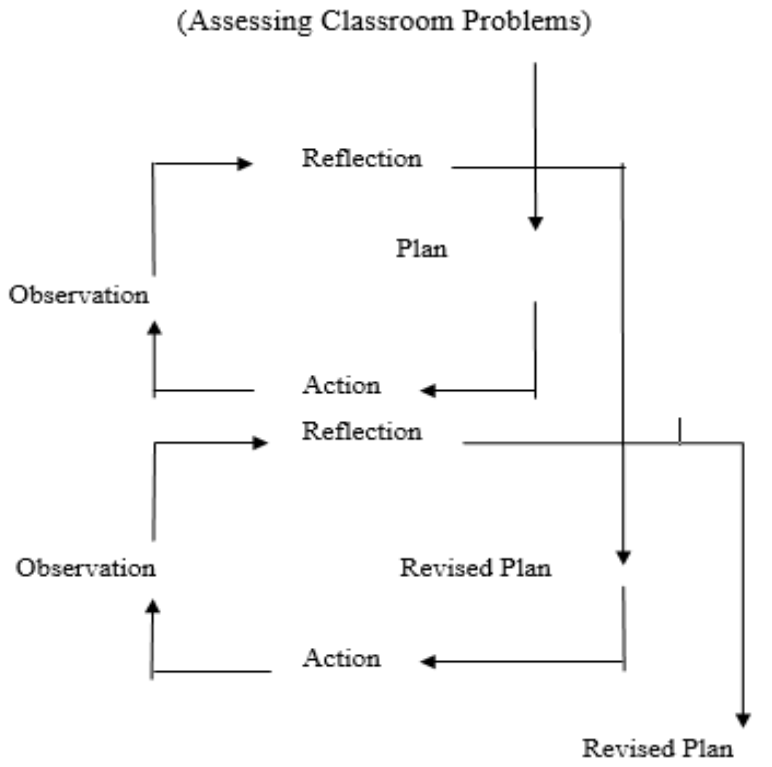

Gambar 1. Alur Pelaksanaan Kegiatan menurut Kemmis \& Mc. Taggert, 1988

Pada siklus pertama dilakukan perencanaan, tindakan, pengamatan dan refleksi. Selanjutnya, pada siklus ke dua yaitu tindakan sebagai langkah perbaikan dari hasil pengamatan serta refleksi dari siklus pertama. Pada tahap perencanaan, peneliti menyusun jadwal penelitian dan istrumen-instrumen pendukung, seperti instrumen observasi dan isntrumen penilaian. Pada tahap pelaksanaan, dilakukan kegiatan implementasi atau penerapan perencanaan tindakan melaksanakan pembelajaran menulis teks naratif dengan menggunakan silent video.

Pada tahap pengamatan terdapat dua kegiatan yang diamati, yaitu kegiatan belajar peserta didik dan kegiatan pembelajaran. Pengamatan terhadap proses belajar peserta didik dapat dilakukan sendiri oleh guru pelaksana (peneliti) sambil melaksanakan pembelajaran. Sedangkan pengamatan terhadap proses pembelajaran, guru pelaksana (peneliti) meminta bantuan kepada teman sejawat yang bertindak sebagai kolaborator untuk melakukan pengamatan. Kolaborator melakukan pengamatan pembelajaran berdasarkan instrumen yang telah disusun oleh peneliti. Hasil pengamatan dari kolaborator nantinya digunakan peneliti sebagai bahan refleksi untuk perbaikan pembelajaran berikutnya.

Kegiatan refleksi dilaksanakan ketika kolaborator sudah selesai melakukan pengamatan terhadap peneliti dalam melaksanakan pembelajaran. Kegiatan ini dapat berupa diskusi hasil pengamatan yang dilakukan oleh kolaborator dengan guru pelaksana (peneliti). Tahap ini merupakan inti dari penelitian tindakan kelas, yaitu ketika kolaborator mengungkapkan hal-hal yang dirasakan sudah berjalan baik dan bagian yang belum berjalan dengan baik pada saat peneliti mengelola proses pembelajaran. Hasil refleksi dapat digunakan sebagai bahan pertimbangan dalam merancang siklus berikutnya. Sehingga pada intinya, refleksi merupakan kegiatan evaluasi, analisis, pemaknaan, penjelasan, penyimpulan, dan identifikasi tindak lanjut dalam perencanaan siklus berikutnya.

Jenis data berupa hasil kerja peserta didik yang kriterianya meliputi kelengkapan struktur teks, ejaan, tanda baca, kosakata dan keutuhan cerita. Sumber data diperoleh dari kegiatan peserta didik pada tahap kegiatan inti, penilaian sikap, dan keaktifan peserta didik. Pengumpulan data dilakukan pada akhir kegiatan pembelajaran pada setiap siklus berupa hasil tulisan pesera didik dan penilaian sikap sebagai hasil observasi selama kegiatan pembelajaran. Instrumen pengumpulan data berupa lembar observasi dan dokumen. Data analisis berupa data kualitatif yaitu lembar hasil menulis peserta didik berupa esai dan dinilai dengan menggunakan rubrik penilaian. Penelitian ini dikatakan berhasil apabila: (a) Aktivitas pembelajaran yang dilakukan guru berkategori Baik, (b) Aktivitas pembelajaran 
yang dilakukan peserta didik berkategori aktif dilaksanakan oleh $80-100 \%$ peserta didik; dan (c) $75 \%$ peserta didik memiliki kemampuan menulis dengan minimal nilai 75 .

\section{Hasil dan Pembahasan}

Hasil penelitian yang diperoleh dipaparkan sebagai berikut:

Tabel 1. Hasil Setiap Aspek PTK pada Siklus I

\begin{tabular}{llll}
\hline No & Aspek Penelitian & Kondisi & Refleksi \\
\hline 1 & Keaktifan peserta didik & $72 \%($ Cukup $)$ & Kegiatan berkelompok belum berjalan maksimal \\
2 & Pelaksanaan pembelajaran & $78 \%$ & $\begin{array}{l}\text { Pengelolaan waktu masih belum diikuti dengan } \\
\text { tepat }\end{array}$ \\
& Keterampilan menulis & Rata-rata 69,9 & $\begin{array}{l}\text { Struktur teks sudah bagus, daya imajinasi masih } \\
\text { kurang, kosakata masih terbatas }\end{array}$ \\
& & Ketuntasan 78\% & kurata \\
\end{tabular}

Tabel 2. Hasil Setiap Aspek PTK pada Siklus II

\begin{tabular}{llll}
\hline No & Aspek Penelitian & Kondisi & Refleksi \\
\hline 1 & Pelaksanaan Pembelajaran & $92 \%$ & $\begin{array}{l}\text { Keseluruhan pelaksanaan pembelajaran sudah } \\
\text { sesuai seperti rencana }\end{array}$ \\
2 & Keterampilan menulis & $\begin{array}{l}\text { Rata-rata 77,3 } \\
\text { Ketunta-san } 94 \%\end{array}$ & $\begin{array}{l}\text { Diskusi kelompok sudah dinamis, daya } \\
\text { imajinasi berkembang dan pemerolehan kosa } \\
\text { kata lebih banyak }\end{array}$ \\
\hline
\end{tabular}

\section{Keaktifan Peserta Didik}

Penilaian sikap dilaksanakan mulai dari awal kegiatan, kegiatan inti yaitu pada saat peserta didik mengerjakan lembar kerja (Activity 1, 2 dan 3). Activity 1: mngerjakan 3 soal secara individu berkaitan dengan pemahaman umum tentang isi cerita dalam video. Activity 2: mengerjakan tugas berkelompok yang berkaitan dengan informasi rinci dan tersirat yang terdapat pada tayangan video. Activity 3: mengerjakan tugas individu yaitu menulis teks naratif secara utuh berdasarkan video dan kegiatan pre aktivity berupa penggalian ingatan dan kosakata yang dilakukan pada pertemuan sebelumnya dan pelaporan hasil tulisan peserta didik. Indikator keaktifan peserta didik meliputi 5 hal yaitu, adanya tindakan bertanya/menyampaikan ide, merespon pertanyaan guru, bekerjasama, bersungguh sungguh serta disiplin.

Tabel 3. Hasil observasi keaktifan peserta didik

\begin{tabular}{llll}
\hline No & Observasi Keaktifan & Siklus 1 & Siklus 2 \\
\hline 1 & $\begin{array}{l}\text { Persentase keaktifan } \\
\text { klasikal }\end{array}$ & $72 \%$ & $86 \%$ \\
2 & Rata2 nilai keaktifan & 3.6 & 4.3 \\
\hline
\end{tabular}

Hasil pengamatan keaktifan peserta didik pada siklus 1 adalah $72 \%$ dan $86 \%$ pada siklus 2. Capaian pada siklus 1 masih dalam posisi bawah batas rentang nilai katagori Baik (70\%-85\%), namun hasil dari kedua menunjukkan bahwa persentase Keaktifan peserta didik telah mencapai target (Baik). Skor Rata rata nilai sikap pada siklus 2 mengalami kenaikan yaitu $86 \%$. Nilai tersebut setara dengan katagori Sangat Baik.

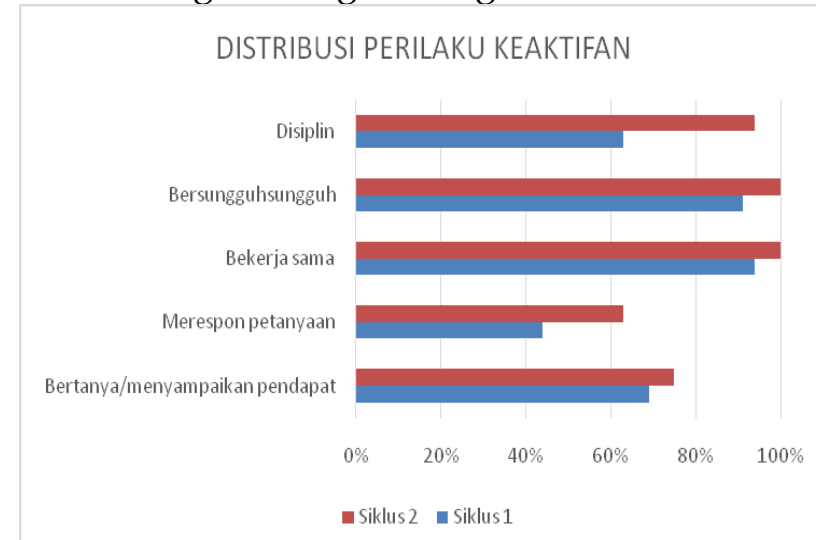

Gambar 2. Hasil Observasi perilaku yang menunjukkan keaktifan.

Grafik diatas menunjukkan rincian perilaku yang menunjukkan keaktifan peserta didik selama mengikuti pembelajaran sejak 
kegiatan awal hingga kegiatan penutup. Perilaku "bekerja sama" dan "bersungguh sungguh" mencapai diatas 90\%. Hal ini menunjukkan bahwa Cooperative Learning telah terlaksana dengan sangat baik, 'Merespon pertanyaan" masih rendah (44\%). Keberanian bertanya atau berpendapat terutama yang berkaitan dengan isi video sudah cukup besar (69 \%) hal ini menunjukkan besarnya upaya untuk mengungkapkan daya imajinasi mereka. Kedisiplinan nampak pada ketepatan waktu kehadiran di kelas, disiplin mengikuti prosedur pembelajaran. Target kedisiplinan masih belum tercapai (69\%) karena hanya 20 anak yang tepat waktu dalam mengumpukan tugas. Hal ini terjadi karena peserta didik masih belum memaksimalkan diskusi kelompok sebagai sarana untuk menggali ide dan memperkaya kosakata.

Sebagai hasil refleksi pada siklus 1, peneliti melakukan pengawasan pada kegiatan diskusi kelompok secara lebih intensif sehingga pada siklus 2 perolehan hasil pengamatan sikap keaktifan khususnya dalam "kerjasama" dan "bersungguh sungguh" meningkat menjadi $100 \%$. Tidak ada satupun peserta didik yang tampak pasif. Hal ini berdampak pula pada peningkatan aspek kedisiplinan pada ketepatan waktu dalam mengerjakan tugas menjadi sebesar $94 \%$. Kondisi ini menunjukkan bahwa keefektifan diskusi adalah faktor terpenting dalam pembelajaran. Kejelasan alur diskusi dan ketegasan instruksi disertai pengawasan yang intensif sangatlah menentukan kualitas hasil diskusi. Kemampuan peserta didik dalam merespon pertanyaan belum mencapai target $(63 \%)$ namun mengalami peningkatan sejumlah $19 \%$ dari siklus sebelumnya. Aktivitas bertanya dan berpendapat pada siklus ke-2 sudah meningkat dan mencapai target yakni sebesar 75\%. Hal ini menunjukkan bahwa keberanian dan rasa percaya diri sudah meningkat. Penilaian oleh teman sejawat nampaknya merupakan pemacu peserta didik untuk melakukan tugas dengan sebaik baiknya.

\section{Keterampilan Menulis Teks Naratif}

Rangkuman hasil penelitian tentang keterampilan menulis adalah sebagai berikut.

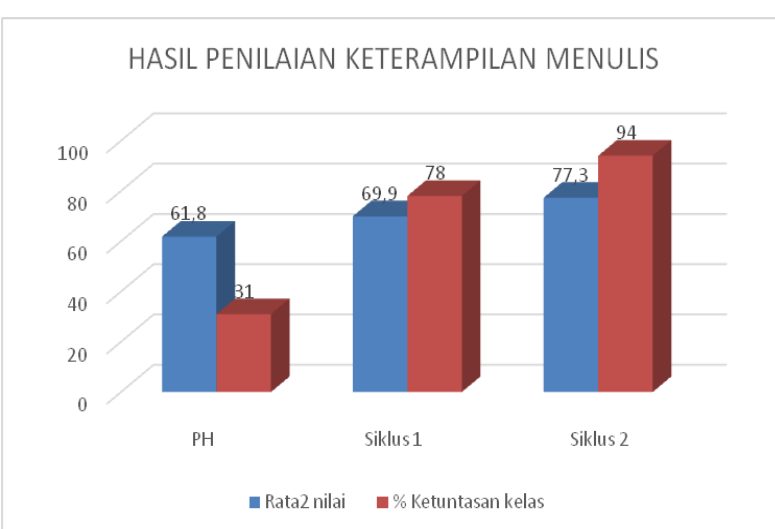

Gambar 3. Hasil penilaian keterampilan menulis

Dari grafik di atas dapat dilihat bahwa telah terjadi peningkatan jumlah nilai rata-rata peserta didik baik pada siklus 1 yaitu 69,9 dan 77,3 pada siklus 2. Prosentase nilai ketuntasan kelaspun meningkatdari $31 \%$ menjadi $78 \%$ di siklus ke-1 dan menjadi $94 \%$ di siklus ke-2. Sebelum dilakukan penelitian jumlah peserta didik yang mendapat nilai dibawah KKM cukup besar yaitu $69 \%$ atau sejumlah 22 orang, pada siklus 1 jumlahnya berkurang menjadi $22 \%$ atau 8 orang. Begitu juga pada siklus 2 terus menurun hingga $0.6 \%$ atau 2 orang. Terbatasnya kosakata bahasa Inggris untuk mengungkapan ide ke dalam kalimat dengan struktur yang tepat merupakan kendala utama dalam menulis teks naratif. Kompetensi struktur kalimat lampau (Past tene, Past Continuous) adalah kompetensi yang seharusnya dimiliki pada saat Kelas X. Penurunan jumlah peserta didik yang tidak tuntas ini tidak lepas dari upaya untuk memperbaiki efektifitas kegiatan diskusi kelompok dengan memberikan bimbingan lebih agar diskusi kelompok terlaksana secara lebih terarah dari siklus ke siklus sehingga pada siklus II seluruh peserta didik sudah mampu bekerjasama dan saling berbagi dalam kelompok.

Adapun hasil yang diperoleh keterampilan menulis teks naratif pada Siklus 1 dan siklus 2 serta hasil Penilaian Harian 
sebelum dilakukan PTK adalah sebagai berikut:

Tabel 4. Distribusi Nilai Berdasarkan Rentang Nilai

\begin{tabular}{llcll}
\hline No & Rentang Nilai & PH & $\begin{array}{c}\text { Siklus } \\
1\end{array}$ & $\begin{array}{c}\text { Siklus } \\
2\end{array}$ \\
\hline 1 & $\begin{array}{l}86-100=\text { Baik } \\
\text { sekali }\end{array}$ & - & 1 & 4 \\
2 & $71-85=$ Baik & 3 & 10 & 18 \\
3 & $61-70=$ Cukup & 11 & 15 & 8 \\
4 & $\leq 60=$ Kurang & 18 & 6 & 2 \\
\hline
\end{tabular}

Perolehan nilai keterampilan menulis didistribusikan dengan rentang nilai dengan katagori Baik Sekali, Baik, Cukup dan Kurang. Kriteria Ketuntasan Minimal (KKM) untuk penilaian ini adalah 70 . Nilai 70 adalah batas tertinggi katagori Cukup.

\section{Pelaksanaan Pembelajaran}

Kolaborator melakukan pengamatan pembelajaran berdasarkan RPP yang telah disusun oleh peneliti. Berikut adalah tabel hasil pengamatan Pelaksanaan Pembelajaran

Tabel 5. Rangkuman Hasil Pengamatan Pembelajaran Oleh Tim Kolaborator

\begin{tabular}{|c|c|c|c|}
\hline \multicolumn{2}{|c|}{ No Tahap Kegiatan } & Siklus I & Siklus II \\
\hline \multicolumn{2}{|c|}{ A. Kegiatan Pendahuluan } & 4 & 4 \\
\hline 1 & Mengondisikan Kelas & 3 & 4 \\
\hline 2 & Memotivasi Siswa & 3 & 4 \\
\hline 3 & Melakukan Apresiasi & 3 & 4 \\
\hline 4 & $\begin{array}{l}\text { Menyampaikan tujuan pembelajaran atau indikator ketercapaian } \\
\text { kompetensi }\end{array}$ & 3 & 4 \\
\hline \multicolumn{4}{|c|}{ B. Kegiatan Inti } \\
\hline 5 & Menunjukkan antusiasme dalam mengajar & 3 & 4 \\
\hline 6 & Menunjukkan relevansi materi pembelajaran dengan kehidupan nyata & 3 & 4 \\
\hline 7 & Memanfaatkan media pembelajaran dengan tepat & 4 & 4 \\
\hline 8 & $\begin{array}{l}\text { Menyajikan langkah pembelajaransesuai sintaks model atau } \\
\text { metode/strategi yang dipilih }\end{array}$ & 4 & 4 \\
\hline 9 & Mengelola kelas sesuai dengan alokasi waktu yang direncanakan & 2 & 4 \\
\hline 10 & Memberi kesempatan peserta didik untuk bertanya & 3 & 4 \\
\hline 11 & Melakukan penilaian sikap & 3 & 4 \\
\hline 12 & Memberikan intruksi dnegan jelas & 3 & 4 \\
\hline 13 & Melakukan monitoring kegiatan belajar peserta didik secara merata & 3 & 4 \\
\hline 14 & Melakukan evaluasi hasil belajar & 3 & 4 \\
\hline \multicolumn{4}{|c|}{ C. Kegiatan Penutup } \\
\hline 15 & Menyimpulkan hasil belajar & 3 & 3 \\
\hline 16 & Melakukan refleksi proses pembelajaran bersama siswa & 4 & 3 \\
\hline 17 & Memberikan tugas tindak lanjut setelah kegiatan pembelajaran & & 3 \\
\hline \multicolumn{2}{|c|}{ Jumlah Skor } & 53 & 63 \\
\hline \multicolumn{2}{|c|}{ Skor Maksimal } & 68 & 68 \\
\hline \multicolumn{2}{|c|}{ Nilai Akhir (Persentase) } & $77,9 \%$ & $92,6 \%$ \\
\hline
\end{tabular}

Keterangan:

Nilai Akhir $=\frac{\text { Skor Perolehan }}{\text { Skor maks }} \times 100 \%$

Ketercapaian:

$$
\begin{aligned}
86 \%-100 \% & =4 \text { (Baik Sekali) } \\
70 \%-85 \% & =3 \text { (Baik) } \\
55 \%-69 \% & =2 \text { (Cukup) } \\
\leq 55 \% & =1 \text { (Kurang) }
\end{aligned}
$$

Pengamatan dilakukan oleh kolaborator dimulai dari kegiatan awal, kegiatan inti sampai dengan kegiatan akhir pembelajaran dengan indikator indikator seperti yang terdapat di dalam tabel. Skor maksimal di setiap indikator instrumen adalah 4 dan skor terendah 1.Penghitingan skor akhir adalah dengan menjumlahkan seluruh skor pada setiap indicator kemudian dibagi dengan jumlah maksimal skor (68). Selanjutnya hasilnya dikonversikan kedalam interval ketercapaian, seperti pada rumus berikut. 


$$
\text { Nilai Akhir }=\frac{53}{68} \times 100 \%=77,9 \%
$$

Nilai 77,9 \% termasuk ke dalam katagori Baik.

Pada indikator No. 9 (Pengelolaan Waktu) tidak memperoleh skor katagori Baik (skor 2). Menurut pengamatan tim kolaborator tampak pada beberapa peserta didik belum mampu menyelesaian tulisananya secara utuh. Pada saat waktu pengerjaan tugas berakhir masih banyak peserta didik yang minta perpanjangan waktu. Kondisi ini terjadi karena pada saat diskusi kelompok peserta didik masih belum menggunakan waktu diskusi secara efektif. Seharusnya di forum diskusi ini adalah peluang yang sangat besar bagi peserta didik untuk sharing dalam upaya memperkaya kosakata dan memperluas daya imajinasi.

Dari 10 indikator penilaian Kegiatan Inti, terdapat 7 indikator yang belum mencapai skor maksimal yaitu belum maksimalnya guru peneliti dalam memotivasi peserta didik, mengaitkan relevansi dalam kehidupan, memberi kesempatan peserta didik untuk bertanya, melakukan penilaian sikap, memberikan instruksi dengan jelas, melakukan monitoring kegiatan belajar peserta didik secara merata, melakukan evaluasi hasil belajar. Hasil observasi tersebut merupakan refleksi dan evaluasi yang digunakan sebagai upaya penyempurnaan tindakan pada siklus berikutnya.

Pada siklus kedua, skor perolehan pada observasi Pelaksanaan pembelajaran sudah meningkat menjadi sebesar 92,6. Katagori Sangat Baik atau meningkat sebesar 14,7 \% Hal ini menunjukkan bahwa guru pelaksana telah melaksanakan kegiatan pembelajaran secara keseluruhan dengan sangat baik.

\section{Kesimpulan}

Berdasarkan hasil analisis dan pembahasan yang telah dipaparkan pada bab sebelumnya dapat disimpulkan bahwa penggunaan silent video dengan pendekatan cooperative learning terbukti secara signifikan dapat meningkatkan keterampilan peserta didik dalam menulis teks naratif. Hal ini ditunjukkan dengan peningkatan perolehan nilai rata-rata peserta yaitu 69,9 pada siklus I menjadi 77,3 pada siklus II dan ketuntasan klasikal meningkat dari dari $78 \%$ pada siklus I menjadi $94 \%$ pada siklus II. Kekatifan siswa juga meningkat dari $72 \%$ pada siklus I menjadi $86 \%$ pada siklus II.

\section{Saran}

Penelitian Tindakan Kelas yang telah dilaksanakan penulis menunjukkan bahwa penggunaan media audio visual khususnya silent video terbukti membantu merangsang imajinasi dan kreatifitas peserta didik dalam menulis teks naratif. Harapan penulis silent video ini dapat memberikan inspirasi bagi para guru khususnya guru bahasa untuk mengujicobakan pada pembelajaran teks naratif atau pada pembelajaran pada materi pembelajaran yang relevan. Dengan segala keterbatasan penulis alangkah baiknya apabila penelitian ini ditindaklanjuti demi upaya menyempurnakan hasil pembelajaran.

\section{Daftar Pustaka}

Agustian, S. (2012). The Effect of Using Video Towards Students' Writing Motivation at the Second Year of State Islamic Senior High School Tembilahan Indragiri Hilir Regency (Doctoral dissertation, Universitas Islam Negeri Sultan Syarif Kasim Riau).

Alviano, F., Oktawati, H., \& Kurniawan, A. E. (2021). An Analysis of Students'ability in Writing Narrative Text at $X$ Grade in SMA N 1 Merangin Academic Year 2019/2020. Selecting, 3(3), 23-30.

Amilia, F. (2018). Pemahaman dan Habituasi untuk Membangun Kompetensi Menulis Praktis dan Ilmiah. Lingua Franca: Jurnal Bahasa, Sastra, dan Pengajarannya, 2(1).

Gultom, N. (2012). Penerapan Media Feature Perjalanan pada Pembelajaran Menulis Karangan Narasi Siswa Kelas X SMA Swasta Teladan Pematangsiantar Tahun 
Pembelajaran 20011/2012 (Doctoral dissertation, UNIMED).

Hayland (2004:09) Hyland, K. (2003). Second Language Writing, New York: Cambridge University Press.

Kemmis, S. \&McTaggart, R. (1988).The Action Research Reader (Third Edition). Victoria: Deakin University Press

Rahman, A., Sudiana, N. and Lasmawan, W., 2017. Pengaruh Implementasi Model Kooperatif Tipe Rally Coach Berbantuan Media Gambar Terhadap Kemampuan Menulis Narasi dengan Pengendalian Kecerdasan Linguistik pada Peserta didik Kelas V Gugus Xiii Kecamatan Buleleng. PENDASI: Jurnal Pendidikan Dasar Indonesia, 1(1), pp.35-44.

Sarıca, H.C., dan Usluel, Y. K. (2016). Pengaruh bercerita digital pada memori visual dan keterampilan menulis. Komputer \& Pendidikan, 94, 298-309.

Warren, S. J. dan Dondlinger, M. J. (2008). A MUVE Menuju Menulis PBL: Efek Lingkungan Pembelajaran Digital yang Dirancang Untuk Meningkatkan Kemampuan Menulis Peserta didik Sekolah Dasar. Jurnal Penelitian Teknologi dalam Pendidikan.41 Nomor 1. 